\title{
Fantasy Motif Metaphors: Magical Powers as Exceptionality in Disney's The Incredibles and Zizou Corder's Lion Boy trilogy
}

\author{
Shelley Chappell
}

While works of the fantasy genre convey literal stories which make sense according to the laws of their fictional worlds, the very impossibilities of these narratives invite further readings of their 'secondary or tertiary levels of meaning' (Bleiler 1983, p.vii; also see McGillis 1996a, p.72; Walsh 1981,p.38). Such readings have been generated through the analytical lenses of allegory, parable, fable, symbol and metaphor. A specific focus upon the operation of metaphor in recurrent fantasy motifs enables a precise analysis of fantasy's secondary levels of meaning. Such a methodology scrutinises fantasy's engagement with cultural assumptions and ideas, highlighting the ideological implications of fantasy and thus verifying fantasy's inherent relevance to reality. This article aims to illustrate the value of this methodology by analysing the motif of magical powers as exceptionality in Disney's The Incredibles (2003) and Zizou Corder's Lion Boy trilogy (2003-2005).

\section{Fantasy Motif Metaphors}

Stith Thompson famously described a motif as 'any item in tales' which is 'out of the ordinary, something of sufficiently striking character to become a part of tradition, oral or literary' (1966, 1: p.19; also see 1950 , p.753). Such a definition of motif has been criticised for being 'both vague and ambiguous; it variously refers to theme, plot (tale type), actor, item (object), or descriptive element' (Apo 1997, pp.563-564). However, motif is a useful term when separated from theme (Daemmrich and Daemmrich 1987, p.188; Abrams 1993, p.121). A motif is best distinguished as a concrete plot element or image at the level of story which conveys an abstract concept or theme at the level of significance. The power of fantasy motifs lies not in their contribution to storyline, but in the figurative significances they carry.

Amotifmetaphor is a particularmanifestation of conceptual metaphor. In their pioneering work on conceptual metaphor, Lakoff and Johnson argue that 'our ordinary conceptual system, in terms of which we both think and act, is fundamentally metaphorical in nature' (1980, p.3). Conceptual metaphors thus permeate our cultures and the ways we think about the world in which we live. However, such metaphors are often only studied in terms of their manifestation at a micro-level in linguistic metaphors embedded in words, sentences, or phrases of texts.

Such an approach is of little use in analysing the figurative function of fantasy as a discourse or genre, for in most narratives in the contemporary fantasy genre the language describing fantastic events is meant to be interpreted on a literal level for the purpose of story. When we read, for example, about a human character transforming into a lion this is not meant to be interpreted as a mere figurative expression of courage but as a literal description of a fantastic event (cf. Black 1962, p.33, p.36). There may be such meaning in the event but the figurative significance is not conveyed through linguistic metaphor. It is evident in the motif structure.

\section{Methodology}

A practicable methodology for analysing motif metaphors reworks well-known terminology. The basic structure of linguistic metaphors framed by Richards (1936) and developed by Black (1962) is theoretically superimposed onto the operation of fantasy motifs. Richards conceptualised linguistic metaphors as composed of three parts - the tenor ('the underlying idea or principal subject which the vehicle or figure means'); the vehicle (the figurative expression or conveyance), and the ground (the common signified or area of relationship shared by tenor and vehicle) (1936, pp.96-100). The meaning of a linguistic metaphor is a product of the interaction between the meanings of the vehicle and the tenor (1936, p.100).

Black further developed Richards' 'interactionist view' of metaphor (Abrams 1993, p.68). In the context of motif metaphors, his most useful idea is his suggestion that the vehicle of a metaphor carries a system of associated implications which serve as a filter through which to understand the tenor. Black highlights how a metaphor selects, emphasises, suppresses, and organises features of tenor by calling up a system of commonplaces related to the vehicle and attributing these to the tenor (1962, pp.44-47). The statement 'man is a wolf' thus allows one to understand the tenor (male human being) through the filter of the vehicle (wolf). According to Black, 
if the man is a wolf, he preys upon other animals, is fierce, hungry, engaged in constant struggle, a scavenger, and so on. Each of these implied assertions has now to be made to fit the principal subject (the man) ... Any human traits that can without undue strain be talked about in 'wolflanguage 'will be rendered prominent, and any that cannot will be pushed into the background.

(1962, p.41)

Certain conceptual metaphors may thus limit perceptions of certain tenors, resulting in what Ortony describes as 'a sort of cognitive myopia' $(1979$, p.6).

However, in regards to motif metaphors the system of associated commonplaces attached to a vehicle depends upon an author's particular construction and development of a motif. For some authors, the wolf is constructed as a positive figure, and such a presentation draws upon a system of associated commonplaces which present the wolf as protector, nurturer, compassionate enemy, and benevolent benefactor. This in turn affects the representation of the tenor, (male) human being. Thus, what any motif metaphor conveys ideologically depends upon the nature of the similarities highlighted between semantic domains (Miller 1979, pp.240-242).

\section{Analysis: Magical Powers as Exceptionality}

To briefly illustrate an analysis of fantasy motif metaphor, there is no better instance than a prominent fantasy motif metaphor in children's fantasy literature: the motif of magical powers as exceptionality. ${ }^{1}$ The possession of magical powers is one of the most basic fantasy motifs and is evident in other very common fantasy motifs such as the witch or wizard, the psychic, or the shape-shifter. This motif may be manifested in ways that offer various figurative meanings, but one foremost metaphor is the possession of magical powers as a signifier of exceptionality. Texts in which this motif metaphor occurs (although with quite different ideological implications) are Disney's The Incredibles and Zizou Corder's Lion Boy trilogy, where this fantasy motif metaphor reflects contemporary cultural concerns about individuality and uniformity.
Both these narratives are set in alternative worlds in which there are several fantastic differences from the world in which we live. The Incredibles establishes a pseudoAmerican society in which some people are born with superpowers but the heyday of the 'Super' era is at an end due to the rise of bogus lawsuits crippling the SuperSamaritan. The film focuses upon a family of 'Supers' who live in disguise, concealing their superpowers, but who come into their own when a disenchanted non-Super develops technology he uses to kill off the Supers of the past and falsely establish himself as a superhero. Corder's Lion Boy series is set in a world in which countries often have slightly different boundaries and names from those we are familiar with and political allegiances are unlike those of our world. The rise of pollution and asthma has resulted in a return to shipping as the primary vehicle of transport (2003 p.12, pp.23-4). Beyond this, however, the major fantastic premise is that Charlie Ashanti, a boy from London (with affiliations in Ghana), can talk Cat. The exchange of blood with a leopard cub when Charlie was a baby resulted in a magical exchange of languages.

In each of these texts, the possession of magical powers is clearly a vehicle for a tenor of exceptionality. The ground, the common signified or area of relationship shared by tenor and vehicle, is distinctiveness and extraordinary ability. Following Max Black's idea that the vehicle of a metaphor serves as a filter through which to understand the tenor, it is evident that the fantastic vehicle of magical powers conveys a number of associated commonplaces which affect the reader's conception of exceptionality. Magical powers are considered to be uncommon and rare, to make people special and powerful, to be valuable, enviable and desirable and to entail responsibility. It is considered that they must be natural, not forced, and that they must not be controlled or simulated by others.

Filtering the tenor of exceptionality through a lens of incredible, magical difference thus implies that exceptionality is a state of rare and enviable difference. If exceptionality is a magical power which is naturally acquired - whether inborn or gained through fortuitous accident - then it is something that cannot be controlled or copied by others. Any forms of human exceptionality which cannot be talked about in these terms are pushed 
into the background or made to seem unnatural. In both the texts I will examine, a tension is thus established between what is represented as genuine, natural exceptionality and forced, or fake, exceptionality. Both texts also illustrate concerns about the levelling and homogenisation of exceptionality.

Two scenes early in The Incredibles are crucial to its particular representation of magical powers as exceptionality. These scenes revolve around Mr Incredible and his wife's ideas about how to raise their son, Dash, who was born after the Super heyday is over and who has thus always had to hide his ability to run incredibly quickly. In the first of these scenes, Dash complains that his mother doesn't 'really mean it' when she encourages him to 'do his best' in school. He is not able to 'do his best' because if he participated as he desired in sports at school his superiority of speed would render any competition unfair and would also blow his family's government-assisted cover. Helen, Dash's mother, explains that:

\section{'Right now, honey, the world just wants us to fit in and to fit in we just gotta be like everyone else.'}

Dash says in reply, 'But Dad always said our powers are nothing to be ashamed of, our powers made us special.'

\section{'Everyone's special, Dash,' she drones in response.}

Dash comments: 'Which is another way of saying no-one is.'

Later, Mr Incredible expresses disbelief when his wife asks him to attend Dash's end-of-grade graduation. Mr. Incredible cannot accept the fact that the Super era is over and he now has to live in hiding, forced to suppress his true selfhood and unable to use his superpowers to help others. He sees the graduation as an example of futile social efforts to superimpose contrived exceptionality over the ordinary in an effort to make it appear extraordinary and laments the way his society 'keep[s] creating new ways to celebrate mediocrity' while persecuting those who are 'genuinely exceptional'.

The motif metaphor of magical powers as exceptionality clearly has powerful ideological implications in these scenes. The Incredibles can be interpreted as contributing to contemporary debates about the apparent levelling of achievement in American schools. In the same year The Incredibles was released, US politician Cheri Pierson Yecke published her exposè, The War Against Excellence: The Rising Tide of Mediocrity in America's Middle Schools, in which she outlines the attempt to 'promote social egalitarianism' in schools 'by coercing students who are gifted/high ability to be like everyone else' (2003, p.1). Yecke writes about this perceived endeavour as an erroneous 'attempt... at social engineering' which aims to homogenise children so that they will not suffer inequity as adults (p.5). In showing the usefulness of $\mathrm{Mr}$ Incredible and Dash's fantastic manifestations of giftedness and high ability and thus endorsing their aversion to suppressing their exceptionality, The Incredibles can be read as a criticism of any real-life efforts to control and redistribute exceptionality. The film's ostensible rejection of social levelling is further evident in its unsympathetic representation of an adult driven mad by the inadequacy he experienced growing up in a society in which Supers were still lauded for their exceptionality.

The mad adult supervillain of The Incredibles began life as Buddy, an all-American boy-next-door who lacked physical exceptionality but wished to conquer the world through industry and determination. As an inspired child, Buddy wants to be Mr Incredible's side-kick. When denied this opportunity, he turns his genius with technical creation to evil ends, creating his own superweapon to kill off Supers. The name he chooses for himself is symbolic: Syndrome. In Syndrome's childhood, before the Supers were pulled from their pedestals by the public they tried to protect, the glory of exceptionality was restricted to a rare few with innate talents. Buddy's new persona is thus symptomatic of an inferiority complex, obvious in his cries when he initially triumphs over $\mathrm{Mr}$ Incredible in battle: he says, 'Am I good enough now? Who's super now?'. It is just this sort of social disease that any perceived movement towards social egalitarianism in American schools is presumably aiming to prevent.

Paradoxically, in the real world, a character like Buddy would fit within the parameters of exceptionality, for he shows an amazing talent from a young age to create superior 
technology. However, The Incredibles establishes his exceptionality as fake because exceptionality is inherently physical in this film. Buddy can only attempt to become exceptional by using technology to enhance his limited physical powers, and his natural exceptionality, based on his brains rather than his body, appears trivial and inauthentic. The film's conclusion, involving Buddy's loss of control over his technology and his defeat by the Incredible family, leaves viewers with a final elitist insinuation that those who aren't born Super shouldn't try to become so or will risk becoming villains; only those who are authentically exceptional should be allowed to express their individuality and use, rather than gain, power.

Whereas in The Incredibles the inference is that 'genuine' exceptionality is rare, limited to a special few, in the Lion Boy universe authentic exceptionality is widespread. The series features numerous exceptional characters, from the Cat-speaking Charlie Ashanti, to his physically striking, super-intelligent parents, to talented circus performers, ${ }^{2}$ to the incredible Seventeen and Twenty-One, Ghanaian twins who braided each other's hair while in their mother's womb, waiting to be born. This overload of magical and otherwise extraordinary characters metaphorically implies that it is the state of being an individual which conveys exceptionality: all creatures are valuable and uncommon simply because they are unique. While exceptionality thus has much broader parameters in the Lion Boy series, and Corder's version of this motif metaphor has quite different ideological implications to Disney's Incredibles, Corder's villains are similarly represented as those who wish to standardise and falsely recreate exceptionality.

The chief villain in the series is the Corporacy. In this fantasy world, 'big companies' like the Corporacy are described as 'bigger than some governments: bigger, richer, stronger, more powerful' (2003, p.328). The Corporacy kidnap people who are extraordinary and use their skills for financial profit. They drug their victims with an insidious 'sweet air' which allows them to retain their skills while losing their capacity for 'independence and free thinking' (2004, p.91). They are then brainwashed to '[b]e the self [they] always dreamed of being!' (2004, pp.75-6) - a self with commercial aspirations and consumerist habits matching those of the Corporacy. Essentially, victims are drugged and indoctrinated into uniformity. Thus, when Charlie is kidnapped by the Corporacy, he fears that ' $[t]$ hey were just going to soak him up until he didn't exist any more. His body would putter blindly about, but his self, his Charlieness, would be gone' (2005, p.157). A Corporacy victim points 'to a small lump in her palm - the size and shape of a baked bean' and tells Charlie, 'My identity ... It's all in there!' (2005, p.185). Her individuality is erased, and her identity is now encompassed in a micro-chip that connects her to the Corporacy Headquarters. Corder's offhand description of the Corporacy HQ as a 'mothership' emphasises the Corporacy's alien, hive mind mentality that assimilates and destroys distinctiveness (2005, p.157).

Corporacy victims are given a fake exceptionality to replace their individuality. They are housed in Communities which are composed of perfect but fake wood, grass, rocks and flowers $(2004, p .132)$. They are fed 'unnaturally delicious food' $(2004$, p.183) and trained to 'talk... in exclamation marks' (2003, p.256) and interact with an over-the-top, smiling sociability that Charlie's mother, Magdalen, describes as 'sick and weird' (2004, p.298). Despite the differences in political countries in Charlie's world, the Corporacy is clearly represented by its physical location, attitude, and mannerisms of speech as American. Corder's exposure of the Corporacy's corruption beneath an apparently friendly exterior, of its attempts to make money at all costs, standardise individuals and industrialise talent, thus figuratively comments upon the perceived undesirable elements of Americanisation. It highlights how those subjected to cultural imperialism are disempowered by processes which appear to celebrate the individual and individuality, but in reality encourage conformity to certain ideals and (consumer) desires.

The figurative concept of the Corporacy clone is literalised when Corder uses the motif metaphor of magical powers as exceptionality to explore concerns about genetic engineering. While they brainwash their kidnapped victims into using their talents for the Corporacy's financial gain, the Corporacy simultaneously steal the genuine exceptionality of those they kidnap by isolating the talents in their genetic code. Replicating such talent genetically allows them to make money in devious and despicable ways. Before the series begins they have found the allergenic gene 
in one cat and then created and distributed 'Allergenie' cats throughout the globe so that people will have to buy asthma medicine from the Corporacy (2005, pp.219220). Analysing Seventeen and Twenty-One will enable the Corporacy to manufacture to order 'quick-fingered children' for industries such as carpet-making (2005, pp.228-9). The actions of the Corporacy are clearly a form of slavery. The enslavement and duplication of those with exceptional talents metaphorically conveys the threat to genuine individuality by those who attempt to make the extraordinary mundane and the mundane extraordinary. The Corporacy imposes uniformity on the natural distribution of talent and manufactures exceptionality.

The meaningful difference between natural and unnatural exceptionality is evident in a comparison between the villainous Corporacy and Corder's hero, Charlie. Charlie acquired his rare talent to talk Cat when he 'was scratched by a baby leopard' and '[s]ome kind of freak genetic exchange happened' $(2005$, p.11). His magical power is natural, however, as the result of a fortuitous accident. His mother says, 'He's modified himself... Here's everybody fussing about genetic modification methods, and young Charlie here's only done it to himself' (2003,p.56). The fact that he has done so makes his exceptionality permissible: it was a genuine evolution, not forced or contrived, and its consequences are wholly benign. Manufactured exceptionality, as practised in the deliberate genetic meddling of the Corporacy, is unfortunate and malignant, as evident in their practice of indoctrination and slavery; their creation of the persecuted, asthma-inducing Allergenies and the sad sabre-tooth tiger, Primo; and, more loosely, in the once fruitful farming land Charlie sails by on his travels, described now as ruined by 'chemicals and genetic modification' (2004, p.252).

In Lion Boy, a joke is made about one of the stupider characters not being able to 'tell the difference between a wizard and a university professor' (2003, p.59); this joke illustrates the major motif metaphor of the series: that magical powers represent exceptionality. By analysing this motif metaphor, we understand that fantasy is endlessly relevant to reality. Neither a series about a boy who speaks to cats or a film about Supers who have to hide their exceptionality is mere escapism. By concretizing the abstract concept of exceptionality into the motif of magical powers and so examining this concept in extreme forms and situations, these fantasies explore ideological issues about individuality, exceptionality, homogenisation, uniformity, authenticity and simulation. Using a methodology for analysing motif metaphors, we can infer that The Incredibles explores concerns about the suppression of innate exceptionality in favour of social equity and implies that only natural, physical talent deserves opportunity and success. We can also deduce that the Lion Boy trilogy criticises the homogenisation evident in the Americanisation of societies and the dangers of genetic engineering, while celebrating the exceptionality inherent in every individual. As I have attempted to demonstrate, analysis of motif metaphors thus illustrates that fantasy is as much a medium for exploring contemporary issues and concerns as any realist novel.

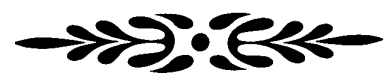

\section{NOTES}

1. For an extended illustration of this methodology in relation to various significant metamorphosis motif metaphors, see Chappell (2007).

2. The Circus is a key motif in the series' theme of exceptionality. It is likened to the Corporacy in the way in which it disempowers animals, namely the lions, using their exceptional being and skills for its own profit (2003,p.140). It also contains aspects of contrived exceptionality in the form of the Learned Pig who appears to be able to count because he has been trained to tap his hoof and in the lions' forced performances which make Maccomo, their trainer, appear exceptional and which hide the fact that the lions are 'really incredibly much clever than this'(2003,p.221). However, Corder's animal characters are given a choice about what they wish to do at the end of the series, and some choose to remain with (or even join) the Circus. The Circus is thus finally opposed to the Corporacy in that it is an avenue in which to celebrate natural exceptionality.

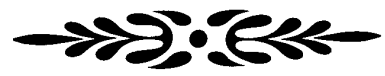




\section{REFERENCES}

Abrams, M. H (1993) A Glossary of Literary Terms. 6th edn. Fort Worth: Harcourt Brace College Publishers.

Apo, Satu (1997) Motif. In Folklore: An Encyclopedia of Beliefs, Customs, Tales, Music, and Art, ed. Thomas A. Green, 563-564. Volume II: I-Z. Santa Barbara, CA: ABC-CLIO.

Black, Max (1962) Models and Metaphors: Studies in Language and Philosophy. Ithaca, New York: Cornell University Press.

Bleiler, Everett F (1983) The Guide to Supernatural Fiction. Kent, Ohio: Kent State University Press.

Chappell, Shelley (2007) Werewolves, Wings, and Other Weird Transformations: Fantastic Metamorphosis in Children's and Young Adult Literature. Diss. Macquarie University. hdl. handle.net/1959.14/226.

Corder, Zizou (2003) Lion Boy. London: Penguin.

_(2004) Lion Boy: The Chase. London: Penguin

(2005) Lion Boy: The Truth. Victoria: Puffin (Penguin).

Daemmrich, Horst S. and Ingrid Daemrich (1987) Themes and Motifs in Western Literature: A Handbook. Tübingen: Francke Verlag. The Incredibles (2003)._Written and directed by Brad Bird. Disney/Pixar. DVD (2005): Buena Vista Home Entertainment.

Lakoff, George and Johnson, Mark (1980) Metaphors We Live By. Chicago and London: The University of Chicago Press.

McGillis, Roderick (1996a) The Nimble Reader: Literary Theory and Children's Literature. New York: Twayne Publishers.

Miller, George A (1979) Images and Models, Similes and Metaphors. In Metaphor and Thought, ed. Andrew Ortony, 202-250. Cambridge: Cambridge University Press.
Ortony, Andrew (1979) Metaphor: A Multidimensional Problem. In Metaphor and Thought, ed. Andrew Ortony, 1-16. Cambridge: Cambridge University Press.

Richards, I. A. (1936) The Philosophy of Rhetoric. New York: Oxford University Press.

Thompson, Stith (1950) Motif. In Funk and Wagnalls Standard Dictionary of Folklore, Mythology, and Legend, ed. Maria Leach, 753. Volume II: J-Z. New York: Funk and Wagnalls.

Thompson, Stith (1966) Motif-Index of FolkLiterature: A Classification of Narrative Elements in Folktales, Ballads, Myths, Fables, Mediaeval Romances, Exempla, Fabliaux, Jest-Books, and Local Legends. Rev. and enl. edn, second printing. 6 vol. Bloomington and London: Indiana University Press.

Walsh, Jill Paton (1981) The Art of Realism. In Celebrating Children's Books, ed. Betsy Hearne and Marilyn Kaye, 35-44. New York: Lothrop, Lee and Shepard.

Yecke, Cheri Pierson (2003) The War Against Excellence: The Rising Tide of Mediocrity in America's Middle Schools. Westport, CT: Praeger Publishers.

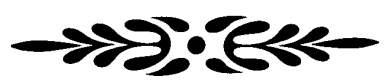

\section{BIOGRAPHICAL NOTE}

Shelley Chappell analysed a number of specific fantasy motif metaphors in her dissertation, which explored the role of fantastic metamorphosis in contemporary children's and young adult fantasy literature. Her research continues in this area, and she is also interested in issues surrounding literature in education. In 2009 she will be working as a teacher of English at St Andrew's College in Christchurch.

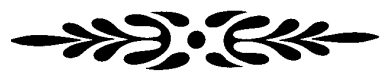

